\title{
O ciałach, które się stają. Feminizm materialny w literaturze dla dzieci i młodzieży
}

\author{
Trites, R. S. (2018). Twenty-first-century feminisms in children's \\ and adolescent literature. Jackson, MS: University Press \\ of Mississippi.
}

Abstrakt:

W artykule recenzyjnym omówiono monografię Twenty-First-Century Feminisms in Children's and Adolescent Literature [Feminizmy XXI wieku w literaturze dziecięcej i młodzieżowej] (2018) autorstwa Roberty Seelinger Trites. Jego celem jest nakreślenie znaczenia tzw. zwrotu materialnego w teorii feministycznej dla badań nad płcią społeczno-kulturową w literaturze dla młodych odbiorców. Artykuł rozpoczyna się od przybliżenia sylwetki Trites i jej poprzednich prac. W kolejnej części przedstawione zostają różne sposoby teoretycznego ujmowania ciała w myśli feministycznej. Przywołanie stanowisk zajmowanych przez Susan Bordo, Judith Butler czy Elizabeth Grosz pomaga stworzyć odpowiednie tło dla podstawowych założeń feminizmu materialnego i teorii Karen Barad. Sproblematyzowanie kwestii ucieleśnionej podmiotowości kobiecej pozwala zarazem wykazać, w jaki sposób zastosowanie przez Trites feminizmu materialnego do badań nad literaturą dziecięcą i młodzieżową wyznacza nowe kierunki analizy i interpretacji. W dalszej części artykułu zostają omówione poszczególne rozdziały książki, w których Trites włącza do dyskusji perspektywy kluczowe dla współczesnych feminizmów, w tym m.in. teorię krytyczną rasy, ekokrytykę, teorię queer oraz studia nad niepełnosprawnością.

* Adrianna Zabrzewska - mgr, przygotowuje rozprawę doktorską w Szkole Nauk Społecznych w Instytucie Filozofii i Socjologii Polskiej Akademii Nauk dotyczącą ciał, głosów i opowieści we współczesnej polskiej i amerykańskiej literaturze dla dzieci i młodzieży. Kontakt: adazabrzewska@gmail.com.

1 Artykuł powstał w ramach Grantu Szkoły Nauk Społecznych Instytutu Filozofii i Socjologii Polskiej Akademii Nauk nr 10/2018. 


\section{Słowa kluczowe:}

ekokrytyka, feminizm, feminizm materialny, literatura dziecięca i młodzieżowa, gender, materialność, Roberta Seelinger Trites, studia nad niepełnosprawnością, teoria krytyczna rasy, teoria queer, ucieleśnienie

\section{Becoming Bodies: Material Feminism in Children's and Adolescent Literature}

Trites, R. S. (2018). Twenty-first-century feminisms in children's and adolescent literature. Jackson: University Press of Mississippi.

\section{Abstract:}

As a review article dedicated to Twenty-First-Century Feminisms in Children's and Adolescent Literature (2018) by Roberta Seelinger Trites, the paper aims to discuss the material turn in feminist theory and its implications with respect to research on gender in literature for young readers. After presenting Trites as a researcher and briefly discussing her earlier works, the author of the article takes a little detour to retrace various approaches to embodied subjectivity in feminist thought. An account of different approaches to the question of corporeality - as expressed in the writings by Susan Bordo, Judith Butler, or Elizabeth Grosz - serves as a background against which the theories of material feminists such as Karen Barad's can be fully displayed. Simultaneously, this discussion sets the scene for showing how Trites's employment of material feminism can be translated into research on literature for children and teenagers in a way that opens new fields of inquiry and new planes of interpretation. The subsequent part of the article discusses each of the chapters of the book to show how questions of mattering, becoming, and knowing in being intersect with perspectives crucial to contemporary feminisms, e.g. critical race theory, ecocriticism, queer theory, and disability studies.

\section{Key words:}

ecocriticism, feminism, material feminism, children's and young adult literature, gender, corporeality, Roberta Seelinger Trites, disability studies, critical race theory, queer theory, embodiment

\section{Wprowadzenie}

D o dwudziestu latach od wydania swojej pierwszej książki Roberta Seelin- ger Trites (2018) wraca do zagadnienia reprezentacji kobiet i dziewcząt w literaturze dziecięcej i młodzieżowej, by uwzględnić najnowsze trendy rozwojowe w myśli feministycznej. Kiedy dwie dekady temu w Waking Sleeping Beauty: Feminist Voices in Children's Novels Trites (1997) analizowała literaturę dla młodych odbiorców pióra XX-wiecznych autorek amerykańskich, 
postawiła sobie za cel wytropienie subwersywnych postaci kobiecych, które przyjmują aktywną postawę, odnajdują głos i szukają poczucia siły w obrębie większej społeczności, przekształcając przy tym pejoratywnie nacechowaną zależność (tu jako antonim niezależności, autonomii, suwerenności) w pozytywną i emancypującą współzależność (tu jako synonim harmonijnego współistnienia opartego na relacjach bliskości). Trzy lata później ukazał się tom Disturbing the Universe: Power and Repression in Adolescent Literature (Trites, 2000), w którym badaczka - wówczas wyraźnie zafascynowana Michelem Foucault - analizowała literaturę młodzieżową pod kątem pojęć władzy i dyscypliny, by ustalić pozycję bohaterek i bohaterów w ramach takich struktur jak rodzina, szkoła, ustrój polityczny, religia. Kolejne lata przyniosły publikację zestawiającą twórczość Marka Twaina oraz Louisy May Alcott (Trites, 2007), a także kognitywistyczne studium fenomenu dorastania w literaturze młodzieżowej (Trites, 2014).

W najnowszej książce autorka stawia sobie za cel omówienie kwestii cielesności w odniesieniu do najbardziej naglących zmian społecznych, kulturowych i technologicznych zachodzących we współczesnym świecie. Punktem wyjścia dla Twenty-First-Century Feminisms in Children's and Adolescent Literature (Trites, 2018) stał się tzw. zwrot materialny [material turn] w teorii feministycznej, który ustanawia ciało jako byt dyskursywny i materialny zarazem, nierozerwalnie splatając ze sobą to, co epistemologiczne z tym, co ontologiczne. Posługując się przykładami z powieści wydanych w latach 2000. - w tym ze znanych również polskim czytelnikom bestsellerów takich jak Igrzyska śmierci Suzanne Collins (2008/2009a, 2009b, 2010) czy Saga księżycowa Marissy Meyer $(2012 / 2017,2013 / 2018,2014 / 2019)$ - autorka dokonuje analizy i interpretacji ucieleśnionych bohaterek dziewczęcych jako bytów materialno-dyskursywnych funkcjonujących na skrzyżowaniu różnych tożsamości, zawsze w relacji do kogoś lub czegoś. Ukazując złożoność związków pomiędzy ucieleśnieniem, językiem i byciem w świecie, włącza do dyskusji perspektywy kluczowe dla współczesnych feminizmów, w tym m.in. teorię krytyczną rasy, ekokrytykę, teorię queer oraz studia nad niepełnosprawnością. Zanim przyjrzę się poszczególnym rozdziałom książki, chcę najpierw odpowiedzieć na pytanie, które pozwoli wykazać wartość teoretyczną opracowania Trites i jego innowacyjny charakter. Pytanie to brzmi: O co właściwie chodzi z tym ciałem?

\section{Jak myśleć o ciele? O zwrocie materialnym w teorii feministycznej}

Choć kreślenie linearnej opowieści o wielogłosowej, pełnej wewnętrznych napięć i sprzeczności teorii feministycznej jest zadaniem trudnym, możemy 
zrekonstruować ścieżkę, jaką proponuje Trites. Zacznijmy więc od tego, że za sprawą Judith Butler i jej foucaultowsko-derridiańskich inspiracji wczesne lata 90. XX wieku stały pod znakiem fascynacji zależnościami występującymi pomiędzy dyskursem, performatywnością, płcią i seksualnością. To właśnie ta autorka - najpierw w książce Uwikłani w płeć. Feminizm i polityka tożsamości (Butler, 1990/2008), a potem w Bodies That Matter: On the Discursive Limits of 'Sex' (Butler, 1993) - sproblematyzowała relację między płcią biologiczną [sex] i płcią społeczno-kulturową [gender], zwracając uwagę na to, że ta pierwsza nie jest predyskursywną, naturalną czy realną podstawą, na którą zostaje nałożona dyskursywna nadbudowa tej drugiej; według Butler, i sex, i gender są społecznymi konstruktami uwikłanymi w powtarzalne praktyki performatywne, które definiują i sankcjonują to, co normatywne, a naznaczają to, co od normy odbiega. Chociaż intencją Butler nie było, jak słusznie zauważa Trites (2018, s. 13), zanegowanie cielesności jako takiej czy stworzenie opozycji między językiem a materią, należałoby dodać, że myśl autorki Gender Trouble: Feminism and the Subversion of Identity (Butler, 1990) spotkała się z oporem tych feministek, które obawiały się, że takie postawienie sprawy odsunie na drugi plan różnicę seksualną i codzienne doświadczenie kobiecego ciała. Obawiano się mianowicie tego, że teoria feministyczna w takim wydaniu będzie się poruszać po wybitnie abstrakcyjnych płaszczyznach, zapominając o ciałach, które nie tylko mogą krwawić i rodzić, lecz także - jak u Susan Bordo (1993) w Unbearable Weight: Feminism, Western Culture, and the Body - o ciałach, które mają kształt, rozmiar, sprężystość, fakturę, a przede wszystkim tytułowy „nieznośny ciężar”; o ciałach, które tyją, chudną, głodzą się, prowokują wymioty; które poddają się mniej lub bardziej inwazyjnym praktykom ubioru, zabiegom kosmetycznym i chirurgicznym, goniąc za nieosiągalnym ideałem i próbując dopasować się do świata, który nie został skrojony do ich potrzeb.

Teoretyczne ujmowanie ciała $\mathrm{w}$ feminizmie nie jest zadaniem ani wdzięcznym, ani łatwym, o czym Trites doskonale wie i czemu daje wyraz w swojej pracy. Zwracając się ku cielesności, myśl feministyczna zbliża się do esencjalizmu, który wskazuje na istnienie swego rodzaju istoty kobiecości, wspólnej dla wszystkich kobiet. Jest to o tyle niebezpieczne, że niweluje wszelkie różnice pomiędzy podmiotami kobiecymi (różnice rasowe, etniczne, klasowe, seksualne, narodowościowe, wiekowe, sprawnościowe), stwarza możliwości wykluczenia kobiet transpłciowych oraz ryzykuje popadnięciem $\mathrm{w}$ ramy myślenia, które nie są wcale tak dalekie od ram maskulinistycznych. Przykładowo, osadzenie kobiecości po stronie natury idzie w parze z ryzykiem osadzenia jej po stronie tego, co w myśleniu patriarchalnym łączy się z naturą - czyli z irracjonalnością, prymitywnością, zwierzęcością, tu waloryzowanymi negatywnie. 
Przymykanie oka na cielesność mogłoby z kolei być czytane jako oznaka tego, co Elizabeth Grosz (1994) w Volatile Bodies: Toward a Corporeal Feminism nazywa somatofobią. Termin ten Grosz przyjmuje na określenie tendencji charakterystycznej dla tych tradycji filozoficznych świata Zachodu, które podkreślają rozdzielność materii i formy, ciała i umysłu, natury i duszy, a przy tym konotują owe binarne pary z dualizmem płciowym, konstruując hierarchię, w której męski rozum wiedzie prymat nad kobiecą irracjonalną cielesnością (s. 5-6). Zadaniem feminizmu według Grosz jest znajdowanie alternatywnych sposobów myślenia o cielesności, gdzie ciało nie byłoby grzesznym ochłapem mięsa, niedoskonałym instrumentem rozumu, maszyną napędzaną wolą i duszą, lecz kreatywnym procesem, nieustającą zmianą, strefą mediacji pomiędzy tym, co wewnątrz, i tym, co na zewnątrz; pomiędzy sobą i innym, naturą i kulturą, jednostką i społeczeństwem (s. 23). W owym alternatywnym modelu myślenia pojedyncza, abstrakcyjna i uniwersalna idea ciała ludzkiego zostałaby więc zastąpiona zróżnicowaną wielością konkretnych ciał o określonych przymiotach. „Nie istnieje wszak ciało jako takie”, przypomina Grosz (1994/2009), „istnieją tylko ciała [wyróżnienie oryginalne] - męskie lub kobiece, czarne, brązowe, białe, duże lub małe - i gradacje pomiędzy nimi” (s. 25).

Napięcia pomiędzy esencjalizmem a konstruktywizmem, materią i dyskursem, teoriami płci społeczno-kulturowej i teoriami różnicy płciowej zaowocowały w końcu próbami znalezienia sposobu na to, by - zamiast wikłać się w kolejne dualizmy - myśleć o wszystkich tych pojęciach łącznie. Jedną z teoretyczek przyjmujących taką postawę jest cytowana Grosz wraz z jej „ciałami lotnymi” (gdzie lotność sugeruje zmienność, ruch, zdolność przemiany, a nawet pewną nieprzewidywalność), ale warto też wspomnieć kilka innych myślicielek, które zwykło się wpisywać w nurt nowego materializmu, a których prace rozszerzają znaczenie terminu "ciało” na ciała ludzi, zwierząt, roślin, na ciała fizyczne i na materię jako taką. Są to: łącząca wykształcenie biologiczne z zainteresowaniem technologią i filozofią Donna Haraway, postać kluczowa dla posthumanizmu i animal studies; zajmująca się kwestiami podmiotowości filozofka Rosi Braidotti, której książki, takie jak Podmioty nomadyczne. Ucieleśnienie i różnica seksualna w feminizmie współczesnym (1994/2009) czy Po człowieku (2013/2014) zostały w całości przetłumaczone na język polski; i w końcu Karen Barad, fizyczka, która w swoich filozoficznych rozważaniach posługuje się odniesieniami do mechaniki kwantowej, teorii Nielsa Bohra oraz zjawisk takich, jak dyfrakcja czy dualizm korpuskularno-falowy. To, co łączy nowe materialistki - jak zauważa Joanna Bednarek (2012) w rozdziale wchodzącym w skład antologii przekładów Teorie wywrotowe - to „wzmożone zainteresowanie mechanizmami wytwarzania rzeczywistości na gruncie nauk 
przyrodniczych" (s. 227-228), które idzie w parze z próbą skorygowania teorii konstruktywistycznych przy jednoczesnym zachowaniu ich najważniejszych osiągnięć. Próba ta wiąże się z podjęciem wysiłku „zakwestionowania podziału na nauki przyrodnicze i humanistyczne, domenę społecznych lub kulturowych konstruktów i przyrodniczych faktów" (s. 227-228). Jak dodają Olga Cielemęcka i Monika Rogowska-Stangret (2018), redaktorki zbioru Feministyczne nowe materializmy. Usytuowane kartografie, przedstawicielki tego nurtu odrzucają „antropocentryzm i androcentryzm, obierając za punkt wyjścia radykalne współkonstytuowanie się bytów ludzkich i nie-ludzkich, naturalnych i technologicznych, organicznych i syntetycznych, materii i języka" (s. 6-7).

W tym zestawie nazwisk centralną inspiracją dla Twenty-First-Century Feminisms... wydaje się Barad, którą Trites przywołuje już w pierwszym rozdziale monografii i do której często powraca. Barad pojawia się tu jako myślicielka, która krytykuje Butler za niewykorzystanie potencjału materialności, ale w żadnej mierze nie oskarża jej o monizm, idealizm czy wykluczenie ciał z krwi i kości (Trites, 2018, s. 8). Jako filozofka z doktoratem z fizyki teoretycznej Barad (2007) $\mathrm{w}$ tomie Meeting the Universe Halfway: Quantum Physics and the Entanglement of Matter and Meaning za podstawową jednostkę ontologiczną przyjmuje nie obiekt o określonych granicach i właściwościach, ale splot intra-aktywnych fenomenów, których nieustające oddziaływanie na siebie definiuje ich właściwości i komponenty. „Świat to dynamiczny proces intra-aktywności, podlegającej ciągłym rekonfiguracjom lokalnie określonych struktur przyczynowo-skutkowych, określających granice, własności, sensy i wzory oznaczeń poszczególnych ciał" (Barad, 2003/2012, s. 343). Prace tej badaczki pozwalają przyjąć, że znaczenie nie występuje ani w samym dyskursie, ani w samej materii, ale w ich wzajemnym i nierozerwalnym splątaniu [entanglement]. Co istotne, ukazując konstytutywną współzależność świata naturalnego i społecznego, posthumanistyczne teorie Barad pozwalają zakwestionować nadrzędną i sprawczą rolę człowieka w procesie tworzenia znaczeń. Jak pisze Ewa Hyży (2017) w artykule poświęconym Barad, a opublikowanym w zbiorze Feministyczne konteksty:

Człowiek nie zajmuje centralnego miejsca w wyjaśnianiu inteligibilności i obiektywności, aktywną epistemiczną wagę mają też inne materialne obiekty. Sprawstwo jest działaniem/byciem w intra-akcji; nie jest atrybutem, lecz trwającym re-figurowaniem świata. Nie jesteśmy „obserwatorami” świata, ani nie mamy w nim szczególnej ontologicznej pozycji i miejsca, jesteśmy jego częścią (s. 71).

Nasze doświadczenie świata jest też doświadczeniem naszego ciała - ciała, które istnieje i działa w świecie. 


\section{Ciało, które się staje. Feminizm materialny w literaturze dla młodych odbiorców}

Choć trudno u Trites oczekiwać pogłębionej interpretacji czy to Barad, czy to deleuziańskich inspiracji u Braidotti, autorka sięga do tych teoretyczek w pierwszym rozdziale książki, by zapożyczyć wybrane pojęcia i zademonstrować, w jaki sposób można zastosować je do analizy literatury dziecięcej i młodzieżowej. Pierwszym pojęciem jest mattering, czyli wspomniany wcześniej proces formowania się - oraz transformowania - znaczenia w intra-aktywnej relacji materii i dyskursu (sam termin należałoby czytać jako grę słów zawierającą w sobie rzeczownik matter, czyli „materia”, oraz czasownik matter, czyli „mieć znaczenie”). Drugim pojęciem, również zapożyczonym od Barad i przetworzonym na użytek własny, jest knowing in being, co można tłumaczyć jako „rozumienie w byciu”, czyli poznanie, które dokonuje się i jest możliwe wyłącznie przez cielesność i ciało, które posiada płeć i przez płeć także siebie rozumie (Trites, 2018, s. 17). Trzecim i ostatnim terminem jest becoming, czyli „stawanie się” rozumiane jako właściwość podmiotu dynamicznego, ruchomego czy wręcz nomadycznego, a więc takiego, który „ilustruje pragnienie tożsamości utworzonej ze stanów przejściowych, następujących po sobie przesunięć, skoordynowanych zmian; bez i przeciwko jakiejś istotowej jedności" (Braidotti, 1994/2009, s. 50). Jest to podmiot przesiąknięty pragnieniem, by mówić i działać, otwarty na zmiany, na przekraczanie i redefiniowanie granic; posiada zdolność negocjowania swojej pozycji w relacjach władzy. Wygląda więc na to, że „stawanie się” jest ruchomym, podlegającym wiecznej zmianie horyzontem, gdzie tożsamości i sposoby ich wyrażania, w warstwie zarówno językowej, jak i cielesnej splatają się ze sobą, na moment określając podmiot $\mathrm{w}$ jego relacji do świata w danym tu i teraz, ale nie próbując go zamknąć w jednej, stałej definicji. „Stawanie się” jest zatem trybem bycia i rozumienia właściwym wiekowi młodzieńczemu i dorastaniu jako takiemu. Jak postuluje autorka, zastosowanie materialnego feminizmu do odczytania literatury dla dzieci i młodzieży pozwala zbadać wpływ fenomenów materialnych na to, jak młode osoby rozumieją płeć, jak ją wyrażają, odgrywają i wcielają w życie; z kolei literatura dla dzieci i młodzieży może wnieść do materialnego feminizmu szansę na zgłębienie etapu życia, który w dużej mierze uwikłany jest w procesy stawania się (Trites, 2018, s. 29-30).

Wychodząc z tego założenia, Trites w pierwszej kolejności bierze na warsztat intersekcjonalność płci, rasy i wieku. W rozdziale drugim autorka zaczyna od przypomnienia, że rasa jest nie tylko społecznym konstruktem, lecz także doświadczeniem żywego ciała. Co więcej, doświadczenie to wyrasta z realiów, 
w których rasa odczytywana jest wizualnie/wzrokowo. Na tej podstawie przypisane zostają jej różne stopnie widzialności [visibility], za którymi idą rozmaite stopnie i rodzaje opresji - a do nich z kolei należy dodać napięcia rodzące się tam, gdzie rasa zbiega się z płcią, klasą, narodowością, seksualnością i innymi zmiennymi, które przekładają się na doświadczenie nierówności społecznej, wykluczenia czy stygmatyzacji. Dodając wiek do splotu rasy i płci, Trites demonstruje jak to, co Maria Nikolajeva (2010) nazywa aetonormatywnością [aetonormativity] (od łac. aetas, czyli wiek, czas), może stanowić kolejny wymiar inności, w którym uprzywilejowana pozycja dorosłych prowadzi z jednej strony do represjonowania podmiotów dziecięcych i nastoletnich, a z drugiej - do poszukiwania przez niedorosłych bohaterów strategii oporu i samoakceptacji. Omówione w tym rozdziale książki (niedostępne w polskim przekładzie) to m.in. wyróżniona Medalem Johna Newbery'ego powieść poetycka Brown Girl Dreaming Jacqueline Woodson (2014) czy Claudette Colvin: Twice Toward Justice Phillipa Hoose'a (2009), powieść faktu o Afroamerykance, która sprzeciwiła się segregacji rasowej w komunikacji miejskiej na kilka miesięcy przed Rosą Parks, ale która - jako gniewna nastolatka z klasy robotniczej - nigdy nie stała się ikoną ruchu na rzecz praw obywatelskich. Ciekawym głosem teoretycznym przywołanym w tym rozdziale jest Michael Hames-García (2011, s. xi), który - wyraźnie zainspirowany Barad - postuluje, by obok intersekcjonalności zacząć mówić też o mnogości [multiplicity] jako o konfiguracji wielu różnych, współkonstytutywnych i współzależnych tożsamości składających się na doświadczenie życia jednej i tej samej osoby.

W rozdziale trzecim Trites wprowadza ekofeminizm jako narzędzie destabilizacji maskulinistycznej wizji świata naturalnego. Wizja ta zasadza się na binarnej opozycji kultury i natury, gdzie ta pierwsza jest domeną męskiego rozumu, a ta druga zostaje połączona $\mathrm{z}$ kobiecością i razem $\mathrm{z}$ nią pojmowana jest jako podległa, nieracjonalna, predestynowana do okiełznania i wzięcia w posiadanie choćby i przemocą. Zamiast pokazywać człowieka jako pana wszelkiego stworzenia, powieści, które poddają się czytaniu ekofeministycznemu - a więc np. propozycje spod znaku realizmu magicznego (Ninth Ward Jewell Parker Rhodes, 2010, czy Kaitangata Twitch nowozelandzkiej pisarki Margaret Mahy, 2005), ale też powieści historyczne, w tym znana polskim czytelnikom Ewolucja według Calpurnii Tate autorstwa Jacqueline Kelly (2009/2016) - przedstawiają gatunek ludzki jako jeden z wielu gatunków współegzystujących na tej planecie w złożonej i skomplikowanej sieci wzajemnych relacji, która wymyka się dychotomicznym konstruktom. Liminalność doświadczenia nastoletniej dziewczęcości pomaga bohaterkom dostrzec, rozpoznać i zakwestionować swoją pozycję w ramach dwóch hegemonicznych porządków: patriarchatu i antropocentryzmu. Wśród wzmiankowanych w tej części teoretyczek znalazły się 
Ynestra King czy Greta Gaard, a także łącząca ekofeminizm z postapokaliptyczną literaturą dla młodzieży Alice Curry.

W rozdziale czwartym Trites omawia kwestię ucieleśnienia w literaturze dystopijnej dla młodzieży, dochodząc do wniosku, że nie wystarczy powołać do życia silne, aktywne postaci dziewczęce, by można było mówić o realizacji projektu feministycznego. Jak wykazuje na przykładzie Igrzysk śmierci Collins czy Córki dymu i kości Laini Taylor (2011/2012, 2011/2013, 2014/2015a, 2014/2015b), powieści dystopijne mogą przejawiać tendencję do sankcjonowania ukierunkowanej na prokreację matrycy heteroseksualnej, w której kobieta jest obiektem homospołecznej wymiany między mężczyznami, i w której nie ma miejsca na kobiecą przyjaźń (Trites, 2018, s. 91-92²). Powieści te, jak twierdzi Trites, utrwalają wizję ciała i umysłu, w której myślenie i działanie zostają przedstawione jako kategorie rozłączne, bohaterki często zdają się na rzekomo bezrefleksyjne podążanie za swoim ciałem, a narracja sytuuje cielesność po stronie tego, co zwierzęce, jak również tego, co uprzedmiotowione. Refleksja nad literaturą dystopijną przez pryzmat feminizmu materialnego pozwala zidentyfikować potrzebę alternatywnych sposobów rozumienia sprawczości, gdzie siła postaci kobiecych przejawiałaby się w czymś więcej niż w samym podejmowaniu działania czy w aktywnym poszukiwaniu heteronormatywnej miłości (s. 119).

Szukając bohaterek, które wychodziłyby poza matrycę heteroseksualną, w rozdziale piątym Trites robi ukłon w stronę teorii queer. Odwołując się do badań Lydii Kokkoli i Kerry Mallan, Trites zauważa, że o ile sama teoria queer przyzwala na wewnętrzne sprzeczności i płynne przejścia między gradientami, o tyle literatura młodzieżowa mówiąca o podmiotach nieheteronormatywnych nierzadko popada w uproszczenia i reprodukuje klisze kulturowe. Dzieje się tak dlatego, że chcąc uporać się z binarnymi opozycjami - czy to w powieściach o nastoletnich lesbijkach (np. The Miseducation of Cameron Post pióra Emily M. Danforth, 2012), czy to w historiach o bohater(k)ach transgenderowych, gdzie relacja cielesności z dyskursywnością jest szczególnie wrażliwa (m.in. Luna Julie Anne Peters, 2004, czy Parrotfish Ellen Wittlinger, 2007) - autorki i autorzy często odwołują się, siłą rzeczy, do pojęć męskości i kobiecości; chwila nieuwagi wystarczy, by wzmocnić stereotyp zamiast go zdekonstruować. Choć próby literackie na tym polu wypadają różnie, to jeśli opowiadają o odnalezieniu drogi do (samo)akceptacji i służą wysubtelnieniu rozumienia płci, rodzaju i seksualności, Trites (2018, s. 155) uznaje je za krok w dobrym kierunku.

2 Zob. też Childs (2014), Sedgwick (1985). 
Dodatkowo, jak zauważa badaczka na samym wstępie książki, gdyby teoria queer była w stanie rozmontować binarne rozumienie płci i rodzaju tak dalece, że pojęcia te całkowicie utraciłyby znaczenie, feminizm stałby się zbędny, a przecież nie o to tutaj chodzi (s. xxiv).

Zakładając, że obie dziedziny wymagają otwartości na cielesność drugiego człowieka, w rozdziale szóstym i ostatnim Trites łączy studia nad niepełnosprawnością (w ujęciu Rosemarie Garland-Thompson czy Patricii A. Dunn) z feministyczną etyką troski (podaną głównie za specjalizującą się w filozofii edukacji Nel Noddings). Zarówno disability studies, jak i etyka troski zostają tu przedstawione jako praktyki materialno-dyskursywne, ponieważ wymagają różnych rodzajów bliskości: dotyku, ciepła, ale też rozmowy, zrozumienia, empatycznego rozpoznania potrzeb drugiej osoby. Za przykład służy tu m.in. główna bohaterka wspominanej już Sagi księżycowej - ciało dziewczyny zostało okaleczone w wyniku wypadku i zrekonstruowane za pomocą cybernetycznych implantów. W tym samym rozdziale autorka wprowadza - choć już na innych przykładach - motyw relacji między narratorem i czytelnikiem nazwanej, za Sarą K. Day (2013), narracyjną intymnością. Posiłkując się refleksją Day, Trites (2018, s. 184) próbuje wykazać, że owe wrażenie intymności, które autorzy i autorki literatury dziecięcej i młodzieżowej mogą kreować narzędziami tekstowymi, nie jest relacją obustronną i wzajemną - a więc nie może być relacją etyczną w wydaniu feministycznym.

Interdyscyplinarność: pożytki i słabości. W stronę całościowej oceny książki

Nie mogę oprzeć się wrażeniu, że to, co stanowi największą zaletę opracowania Trites i decyduje o jego innowacyjności, może być też, paradoksalnie, jego największą słabością. Nagromadzenie wątków i tekstów sprawia, że czasami traci się z oczu to, co powinno, jak mi się wydaje, tworzyć oś, która przecina całą książkę i spaja ze sobą różne perspektywy teoretyczne, a więc triadę pojęć: becoming, mattering, knowing in being. $\mathrm{Z}$ tej przyczyny może pojawić się wątpliwość, czy pojęcia te zostały zdefiniowane, zaadaptowane i zastosowane na tyle sprawnie, by ich potencjał analityczny mógł zostać w pełni wykorzystany. Interdyscyplinarne podejście, z jednej strony, oferuje szersze, bardziej przekrojowe spojrzenie, ale z drugiej strony - wiąże się zarówno z niosącym wrażenie chaosu i nadmiaru eklektyzmem, jak i z ryzykiem spłycenia dyskusji tam, gdzie domagałaby się ona pogłębienia. Szczególny niedosyt pozostawia rozdział szósty, a to być może dlatego, że do omówienia feministycznej etyki 
troski nie wystarczy powołanie się na samą Nel Noddings. W moim odczuciu brakuje tu szerszego tła, które pozwoliłoby na stworzenie kontekstu wykazującego odrębność i potencjalną subwersywność relacyjnego charakteru feministycznej etyki troski w odniesieniu do etycznych relacji i spotkania z Innym w maskulinistycznej filozofii kontynentalnej. Wątek narracyjnej intymności zostaje podjęty jedynie na moment $\mathrm{w}$ charakterze dygresyjnego suplementu i pozostawia za sobą więcej pytań niż odpowiedzi.

Kolejną kwestią, bardziej dla mnie istotną, jest decyzja o pominięciu bohaterów chłopięcych. Decyzja ta została podjęta świadomie, a Trites (2018, s. xxiv) motywuje ją charakterem i objętością publikacji, zaznaczając, że na temat spotkania feminizmu materialnego ze studiami nad męskością można by napisać osobną książkę - co jest bardzo dobrym pomysłem, ale jeszcze lepszym (a do tego stycznym z ogólną wykładnią tego opracowania i z wieloma założeniami feminizmu materialnego jako takiego) byłoby myślenie i pisanie męskości oraz kobiecości, dziewczęcości, a także chłopięcości w relacji do siebie nawzajem, a nie osobno. W tym przypadku sugeruję spojrzeć na tę kwestię nie jak na problem, ale raczej jak na inspirację dla dalszej dyskusji.

Wszystkie niedociągnięcia schodzą jednak na dalszy plan, kiedy pomyśli się o wkładzie, jaki książka wnosi do badań nad literaturą dziecięcą i młodzieżową. Wsłuchując się w echa teorii feministycznych, rezonujące w tekstach literackich, Trites stosuje założenia wypracowane przez owe teorie, by nie tylko unaocznić, lecz także sproblematyzować sposób, w jaki współczesna (głównie północnoamerykańska) literatura dla młodych odbiorców porusza zagadnienie płci społeczno-kulturowej. Uwypuklenie znaczenia zwrotu materialnego $\mathrm{w}$ feminizmie dla wszystkich omawianych perspektyw teoretycznych, a także zastosowanie wątku ucieleśnienia jako spoiwa łączącego ze sobą poszczególne rozdziały, jest pomysłem ciekawym, nawet nowatorskim. Wartość teoretyczna opracowania nie ulega wątpliwości, a wywody autorki są dobrze zakorzenione zarówno w tekstach feministycznych (obok przytoczonych nazwisk nie zabrakło tu Simone de Beauvoir, Susan Hekman, Patricii Hill Collins czy Teresy de Lauretis), jak i w badaniach nad książką i kulturą dziecięcą oraz młodzieżową (m.in. Beverly Lyon Clark, Victoria Flanagan, Kimberley Reynolds, Karen Coats, Ruth Bottigheimer, Jack Zipes). Duży respekt budzi warsztat pisarski autorki, a zwłaszcza sprawność, z jaką przeplata rozważania teoretyczne $\mathrm{z}$ materiałem ilustracyjnym, kreśląc plastyczne acz zwięzłe opisy tekstów źródłowych. Co więcej, zwrócenie uwagi na to, jak teorie feministyczne znajdują swoje odzwierciedlenie w amerykańskiej literaturze dla młodych odbiorców, i jak pisarze i pisarki odpowiadają (świadomie lub nie, bardziej udanie lub mniej, implicite lub explicite) na zmiany zachodzące w postrzeganiu płci 
społeczno-kulturowej, może mieć też walor dydaktyczny przy pracy ze studentkami i studentami, także - a może nawet: przede wszystkim - w polskim systemie edukacji. Tak przedstawiony feminizm nie jest bowiem ideologicznym narzędziem, przez które odczytuje się współczesną literaturę dla dzieci i młodzieży w sposób mechaniczny, powierzchowny, oderwany i od argumentów tekstowych, i od rzeczywistości pozatekstowej. Wartości, założenia i cele charakterystyczne dla kobiecych ruchów społecznych przenikają do tej literatury i prowadzonych nad nią badań, a autorzy i autorki coraz częściej poszukują treści i środków wyrazu, które postulują równouprawnienie kobiet i mężczyzn oraz uczą uważniejszego, opartego na szacunku obcowania ze światem.

Książkę można swobodnie polecić badaczkom i badaczom chcącym uwzględnić w swoich pracach perspektywy, które w dużej mierze pozostają nieobecne w polskiej refleksji nad literaturą dziecięcą i młodzieżową. Rzetelny przegląd literatury przedmiotu sporządzony przez Trites na samym wstępie oraz liczne nawiązania do specjalistek i specjalistów dziedzinowych w każdym z rozdziałów pozwolą polskim czytelniczkom i czytelnikom rozeznać się w anglojęzycznych badaniach nad płcią i seksualnością w literaturze oraz kulturze dla młodych odbiorców, poznać najnowsze prądy teoretyczne, a także zidentyfikować zarówno punkty wyjścia do dalszej dyskusji, jak i białe plamy na mapie polskiego literaturoznawstwa i kulturoznawstwa.

\section{Bibliografia}

Barad, K. (2007). Meeting the universe halfway: Quantum physics and the entanglement of matter and meaning. Durham, MD, London: Duke University Press.

Barad, K. (2012). Posthumanistyczna performatywność. Ku zrozumieniu, jak materia zaczyna mieć znaczenie (J. Bednarek, tłum.). W: A. Gajewska (red.), Teorie wywrotowe. Antologia przekładów (s. 323-360). Poznań: Wydawnictwo Poznańskie. (wyd. oryg. 2003).

Bednarek, J. (2012). Powrót „rzeczywistości”. W: A. Gajewska (red.), Teorie wywrotowe. Antologia przekładów (s. 227-240). Poznań: Wydawnictwo Poznańskie.

Bordo, S. (1993). Unbearable weight: Feminism, Western culture, and the body. Berkeley, CA: University of California Press.

Braidotti, R. (2009). Podmioty nomadyczne. Ucieleśnienie i różnica seksualna w feminizmie współczesnym (A. Derra, tłum.). Warszawa: Wydawnictwa Akademickie i Profesjonalne. (wyd. oryg. 1994).

Braidotti, R. (2014). Po człowieku (J. Bednarek, A. Kowalczyk, tłum.). Warszawa: WN PWN. (wyd. oryg. 2013). 
Butler, J. (1990). Gender trouble: Feminism and the subversion of identity. New York, NY, London: Routledge.

Butler, J. (1993). Bodies that matter: On the discursive limits of 'sex.' New York, NY, London: Routledge.

Butler, J. (2008). Uwikłani w płeć. Feminizm i polityka tożsamości (K. Krasuska, tłum.). Warszawa: Wydawnictwo Krytyki Politycznej. (wyd. oryg. 1990).

Childs, A. M. M. (2014). The incompatibility of female friendship and rebellion. W: S. K. Day, M. A. Green-Berteet, A. L. Montz (red.), Female rebellion in young adult dystopian fiction (s. 187-201). Burlington, VT: Ashgate.

Cielemęcka, O., Rogowska-Stangret, M. (2018). Feministyczne nowe materializmy. Usytuowane kartografie. W: O. Cielemęcka, M. Rogowska-Stangret (red.), Feministyczne nowe materializmy. Usytuowane kartografie (s. 6-12). E-naukowiec: Lublin.

Collins, S. (2009a). Igrzyska śmierci (M. Hesko-Kołodzińska, P. Budkiewicz, tłum.). Poznań: Media Rodzina. (wyd. oryg. 2008).

Collins, S. (2009b). W pierścieniu ognia (M. Hesko-Kołodzińska, P. Budkiewicz, tłum.). Poznań: Media Rodzina.

Collins, S. (2010). Kosogłos (M. Hesko-Kołodzińska, P. Budkiewicz, tłum.). Poznań: Media Rodzina.

Danforth, E. M. (2012). The miseducation of Cameron Post. New York, NY: Harper Collins.

Day, S. K. (2013). Reading like a girl: Narrative intimacy in contemporary American young adult literature. Jackson, MS: University Press of Mississippi.

Grosz, E. (1994). Volatile bodies: Toward a corporeal feminism. Bloomington, IN: Indiana University Press.

Grosz, E. (2009). Przeobrażanie ciał (M. Michalski, tłum.). Pobrane z: http://www. ekologiasztuka.pl/grosz.pdf. (wyd. oryg. 1994).

Hames-García, M. (2011). Identity complex: Making the case for multiplicity. Minneapolis, MS: University of Minnesota Press.

Hoose, P. (2009). Claudette Colvin: Twice toward justice. New York, NY: Square Fish.

Hyży, E. (2017). Dzielenie się światem. Nowy feministyczny realizm w ujęciu Karen Barad. W: E. Hyży (red.), Feministyczne konteksty. Multidyscyplinarnie (s. 57-79). Toruń: Wydawnictwo Adam Marszałek.

Kelly, J. (2016). Ewolucja według Calpurnii Tate (K. Rosłan, tłum.). Warszawa: Dwie Siostry. (wyd. oryg. 2009).

Mahy, M. (2005). Kaitangata twitch. Crows Nest, NSW: Allen.

Meyer, M. (2017). Saga księzycowa. Cinder (M. Grajcar, tłum.). Słupsk: Papierowy Księżyc. (wyd. oryg. 2012).

Meyer, M. (2018). Saga księżycowa. Scarlet (M. Grajcar, tłum.). Słupsk: Papierowy Księżyc. (wyd. oryg. 2013). 
Meyer, M. (2019). Saga księżycowa. Cress (M. Grajcar, tłum.). Słupsk: Papierowy Księżyc. (wyd. oryg. 2014).

Nikolajeva, M. (2010). Power, voice, and subjectivity in literature for young readers. New York, NY, London: Routledge.

Peters, J. A. (2004). Luna: A novel. New York, NY: Little.

Rhodes, J. P. (2010). Ninth ward. New York, NY: Little.

Sedgwick, E. K. (1985). Between men: English literature and male homosocial desire. New York, NY: Columbia University Press.

Taylor, L. (2012). Córka dymu i kości (J. Wolin, tłum.). Warszawa: Amber. (wyd. oryg. 2011).

Taylor, L. (2013) Dni krwi i światła gwiazd (J. Wolin, tłum.). Warszawa: Amber. (wyd. oryg. 2011).

Taylor, L. (2015a). Sny bogów i potworów, część pierwsza (J. Wolin, tłum.). Warszawa: Amber. (wyd. oryg. 2014).

Taylor, L. (2015b). Sny bogów i potworów, część druga (J. Wolin, tłum.). Warszawa: Amber. (wyd. oryg. 2014).

Trites, R. S. (2018). Twenty-first-century feminisms in children's and adolescent literature. Jackson, MS: University Press of Mississippi.

Trites, R. S. (2014). Literary conceptualizations of growth: Metaphors and cognition in adolescent literature. Amsterdam, Philadelphia, PA: John Benjamins.

Trites, R. S. (2007). Twain, Alcott, and the birth of the adolescent reform novel. Iowa City, IA: University of Iowa Press.

Trites, R. S. (2000). Disturbing the universe: Power and repression in adolescent literature. Iowa City, IA: University of Iowa Press.

Trites, R. S. (1997). Waking Sleeping Beauty: Feminist voices in children's novels. Iowa City, IA: University of Iowa Press.

Wittlinger, E. (2007). Parrotfish. New York, NY: Simon \& Schuster.

Woodson, J. (2014). Brown girl dreaming. New York, NY: Penguin. 